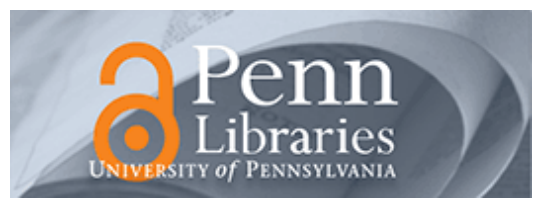

University of Pennsylvania

ScholarlyCommons

\title{
The dangling carrot: Proprietary institutions and the mirage of college choice for Latina students
}

Amalia Z. Dache-Gerbino Ph.D.

University of Pennsylvania, adache@upenn.edu

Judy Marquez Kiyama Ph.D.

Morgridge College of Education

Vicki T. Sapp Ph.D.

Geisinger Commonwealth School of Medicine

Follow this and additional works at: https://repository.upenn.edu/ahead_papers

\section{Recommended Citation}

Dache-Gerbino, A., Marquez Kiyama, J., \& Sapp, V.T. (2018). The dangling carrot: Proprietary institutions and the mirage of college choice for Latina students. The Review of Higher Education, 42(1), 29-60

Pre-print copy of the article originally published in The Review of Higher Education Fall 2018, Volume 42, No. 1, pp. 29-60 Copyright (C) 2018 Association for the Study of Higher Education Published by Johns Hopkins University Press

This paper is posted at ScholarlyCommons. https://repository.upenn.edu/ahead_papers/6

For more information, please contact repository@pobox.upenn.edu. 


\title{
The dangling carrot: Proprietary institutions and the mirage of college choice for Latina students
}

\begin{abstract}
The proximity of proprietary institutions to working-class urban areas is rarely explored as a factor in Latina student college choice. Utilizing Chicana Feminism as a conceptual lens, this study explores the path of proprietary college choice for Latina high school students. Qualitative interviews and geographic data reveal how factors of race, gender, and class contribute to the marketing and location of proprietary institutions. The authors argue that marketing expensive vocational programs to Latina students who cannot afford tuition contributes to the maintenance of racist, classist, and sexist hierarchies.
\end{abstract}

\section{Keywords}

college choice, Latina, working-class, for-profit institutions, marketing, race, gender, class

\section{Comments}

Pre-print copy of the article originally published in The Review of Higher Education Fall 2018, Volume 42, No. 1, pp. 29-60 Copyright @ 2018 Association for the Study of Higher Education Published by Johns Hopkins University Press

\section{Copyright/Permission Statement} (c) $(7) \odot$

This work is licensed under a Creative Commons Attribution-Noncommercial-No Derivative Works 4.0 License. 


\title{
The dangling carrot: Proprietary institutions and the mirage of college choice for Latina students
}

\author{
Amalia Dache-Gerbino, Ph.D. \\ Judy Marquez Kiyama, Ph.D. \\ Vicki T. Sapp, Ph.D.
}

Pre-print copy of the article originally published in The Review of Higher Education

Fall 2018, Volume 42, No. 1, pp. 29-60

Copyright (C) 2018 Association for the Study of Higher Education

Published by Johns Hopkins University Press

DOI: https://doi.org/10.1353/rhe.2018.0033

Amalia Dache-Gerbino is an Afro-Cuban American scholar who is an Assistant Professor of Higher Education at The University of Missouri. Her major research areas include the postcolonial geographic contexts of higher education, community and student social justice activism, and spatial discourses contributing to urban and post-urban college accessibility. Dr. Dache-Gerbino's research was nationally recognized and awarded the Association for the Study of Higher Education's (ASHE) 2014 Bobby Wright Dissertation of the Year. Her research has been accepted or published in other leading education journals such as Teachers College Record and Equity \& Excellence in Education.

Judy Marquez Kiyama, Ph.D., is an associate professor in the Department of Higher Education at the Morgridge College of Education, University of Denver. Her research examines structures that shape college access opportunities for underserved groups to better understand the collective knowledge and resources drawn upon to confront, negotiate, and (re)shape such structures. She can be reached at Judy.Kiyama@du.edu.

Dr. Vicki T. Sapp is currently the Director of Student Affairs for Student Engagement, Diversity and Inclusion and Assistant Professor in the Department of Clinical Sciences at the Geisinger Commonwealth School of Medicine. Her research focuses on leadership development, first generation and student of color populations, college access, retention and success, experiences beyond the baccalaureate and social justice, diversity and inclusion.

Direct all correspondence to Amalia Dache-Gerbino: adache@upenn.edu 


\begin{abstract}
The proximity of proprietary institutions to working-class urban areas is rarely explored as a factor in Latina student college choice. Utilizing Chicana Feminism as a conceptual lens, this study explores the path of proprietary college choice for Latina high school students. Qualitative interviews and geographic data reveal how factors of race, gender, and class contribute to the marketing and location of proprietary institutions. The authors argue that marketing expensive vocational programs to Latina students who cannot afford tuition contributes to the maintenance of racist, classist, and sexist hierarchies.
\end{abstract}




\section{Introduction}

The path to college in urban areas is besieged with geographic, social, and cultural barriers that create more of an obstacle course than a direct route for students of color. Urban areas in the U.S. have seen significant decline in economic development and local educational resources (Sanchez, Stolz, \& Ma, 2003), especially urban areas that have suffered deindustrialization (Dache-Gerbino, 2017). The growth of proprietary institutions ${ }^{1}$ in urban areas is a modern phenomena emerging in these geographies since 1998 (Fisher, 2012) and have been understudied areas especially when considering them as an enrollment option for Latina students residing in low-income urban settings.

Literature exploring student college-choice and the active and normative recruiting practices utilized by proprietary institutions is nearly non-existent (Campbell \& Deil-Amen, 2012; Iloh \& Tierney, 2014). The purpose of this study is to explore the path of proprietary college choice for Latina high school students in an urban school district from the lens of Chicana Feminism. Qualitative and geographic data analysis revealed how race, gender, and class contributed to the proximity of local colleges to Latina/ $\mathrm{o}^{2}$ neighborhoods, targeted marketing by proprietary institutions at urban high schools, and shifts in college choice decisions as Latina students enter higher grades. In addition, there exist layers of complexity when comparing how students rationalize their choices of attendance in community college and proprietary institutions (Iloh \& Tierney, 2014). For instance, Iloh and Tierney (2014) state that there exist "larger social and institutional factors mediating college choice" for participants in their study (p. 27). The students who attended for-profit institutions noted the following factors as influences of their college choice: immediate employment opportunities, convenience, ease 
and pace of access, clear admissions information, and long-term benefits outweighing educational debt, among others (Iloh \& Tierney, 2014).

Thus, we engaged in a qualitative and geographic study utilizing a Chicana Feminist framework to examine the college choice process of sixteen Latinas. Our goal was to understand the factors influencing their college choice decisions, including how Latina students made sense of the nature of recruitment strategies used by proprietary institutions. Focusing on Latina participants was an important and intentional choice as literature suggests that Latina/os and women are often overrepresented among racial, ethnic, and gender groups when examining attendance at proprietary institutions (Iloh \& Tierney, 2014). The Latinas in this study primarily identify as Puerto Rican, a significant contribution because as Nieto $(1998,2004)$ points out, most studies focus on Mexican or Mexican American students even though Puerto Rican students have a rich history of attending U.S. schools but remain one of the most undereducated groups (Kiyama, Harris, \& Dache-Gerbino, 2016). Additionally, in a study of college enrollment decisions comparing Mexican American and Puerto Rican students, Nuñez and Crisp (2012) found that nearly half of their Puerto Rican respondents attended a four-year institution compared with only $28 \%$ of Mexican American students. Thus, our study explores an understudied sub-set of Puerto Rican Latinas, those who have chosen instead to attend proprietary institutions and who live in low-income, urban areas.

In Bergerson's (2009) review of college choice and access literature, she argues that “intensive qualitative studies would contribute to developing this body of research by exploring in depth the individual choice process of students from populations underrepresented in higher education and further illuminating systemic inequities that shape their choice processes and 
decisions" (p. 35). Guided by this call to inquiry, the research questions informing our study include:

1. What factors influence the college choice decisions of Latina students from lowincome urban areas as they consider proprietary institutions?

2. How does a Chicana feminist analysis further explain the college choice decisions of Latinas from low-income areas as they consider proprietary institutions?

In addressing these questions, we are guided by Chicana feminism (Bernal, 1998) as it relates to student markets (Slaughter \& Rhoades, 2004). The contributions of this article are significant for many reasons. First, we present the role of proprietary institutions in the college-choice process for Latinas - a frequent entry-point for Latinas (Aud et. al, 2010), yet infrequently investigated in the literature. We do so while also sharing the Latinas' perspectives about the marketing and recruitment practices of proprietary institutions. Second, our geographic sequential design leads with the qualitative data followed by geographic data analysis based on U.S. Census data. While qualitative designs capturing students' proprietary decisions and enrollment exist, the addition of mapping and geographic methods adds a new dimension to the discussion. These points together have been overlooked and understudied in the area of college access and choice and can further illuminate policy and practice implications that challenge the possible channeling of urban Latina students to proprietary institutions.

We begin the sections that follow by first reviewing Latina/o college access and enrollment literature followed by a review of the role of proprietary institutions. Next, we explain the use of our conceptual framework, drawing on Chicana Feminist Epistemology. We then address our methodology choices and move into a discussion of the findings. We conclude the paper with a discussion of implications for practice, policy, and future research. 


\section{Review of the Literature}

\section{Latina/o college access and enrollment}

By the year 2050, Latina/os will make up a quarter of the national population (Chapa \& De La Rosa, 2004). On the surface, recent data indicates gains in high school degree attainment and college enrollment for Latina/o students (Pew Research Center, 2013). For example, in 20112012, the percentage of Latinas/os who graduated on time from public high schools was reported at 76 percent, an increase from previous years (National Center for Education Statistics [NCES], 2014). Researchers have noted that in 2012, for the first time ever, Latina/o students enrolled in college at two percentage points higher than their white peers, at 69 percent and 67 percent, respectively (Pew Research Center, 2013). Yet, the high school dropout rate for Latina/o students during the same year remained nearly three times the dropout rate of their white peers, at 14 percent and 5 percent, respectively (Pew Research Center, 2013).

Using 2008 undergraduate enrollment indicators for two-year, four-year, public, private, non-profit, and for-profit statistics, Latina/os were only $12 \%$ of the college student population (Aud et. al, 2010). However, when looking at the type of higher education institution and its Latina/o enrollment, two-year public intuitions and for-profit institutional enrollment had the highest Latina/o enrollment (17\% and 13\% respectively; Aud et. al, 2010). Latina/os and African-American students were the two racial groups that had higher undergraduate enrollment at for-profit institutions ( $13 \%$ and $27 \%$ respectively) than the national average of undergraduate enrollment across institutional type (12\% Latina/os, 14\% Black; Aud et. al, 2010). Neither White nor Asian student enrollment at for-profit institutions (52\% and 6\%, respectively) were higher than their national undergraduate enrollment across institutional type $(63 \%$ and $7 \%$, respectively). There is minimal exploratory research seeking to understand this racial/ethnic 
discrepancy. Furthermore, the states with the highest proportions of proprietary institutions are the states with the highest population density (California, Texas, Illinois, Pennsylvania, New York; Chung, 2008), a point especially relevant to our study as we examine Latina college access within a county in Western New York.

When disaggregating the data of college enrollment and conferred degrees by gender, Latinas enroll (10\%) and earn bachelor's degrees (7\%) at exceptionally low rates (Turner, 2008). Although Latinas are "reversing a historical trend of academic failure" and achieve at rates statistically higher than Latino males, the pace at which this trend is reversing continues to place Latinas at social, economic, and educational disadvantages (Cammarota, 2004, p. 55). One option for post-secondary degree attainment, particularly for low-income and students of color is proprietary institutions (Outcalt \& Schirmer, 2003). Yet, the ability to pay off student loans while obtaining "gainful employment" after attending a for-profit institution is a pressing higher education policy concern (U.S. Dept. of Education, 2011). As illustrated, students of color are attending proprietary institutions at higher rates (Outcalt \& Schirmer, 2003) and are concurrently facing higher student loan debt (U.S. Dept. of Education, 2011).

Factors influencing enrollment. When compared to other racial/ethnic groups, Latina/os were less involved in an extensive college choice process (Hurtado, Inkelas, Briggs, \& Rhee, 1997). Thus it is relevant to briefly review the multiple factors influencing where Latina/o students attend college. Important to this study's focus of college choice, geography, and proximity, literature suggests that local higher education context is a major factor in where Latina/o students apply to college (Nuñez \& Crisp, 2012; Perna \& Titus, 2004: Sapp, Kiyama, \& Dache-Gerbino, 2016)), as is the broader political and economic context (Perna \& Titus, 2004). Within the political and economic context, immigration policies, access to and quality of 
bilingual education were factors impacting college-choice for Latina/o students (Nuñez \& Crisp, 2012). At the micro-level, Latina college choice literature describes family context and youth centric factors as having significant impact on choosing colleges (Alvarez, 2010; Nuñez \& Crisp, 2012). Specific to the family context are factors such as family income, culture, collectivism, familism, proximity to family, and parents' level of education (Nuñez \& Crisp, 2012; Mendoza, Hart, \& Whitney, 2011; Santiago, 2007; Sapp et al., 2016). The role of familism or familismo are fundamental to the dynamics of Latina/o decision-making (Alvarez, 2010; Ovink, 2014; Perez \& McDonough, 2008). Central to the cultural belief of familismo are attitudinal, behavioral, and structural dynamics, including the importance of maintaining strong family ties, drawing on family for support, loyalty, and commitment to family over individual needs (Mendoza et al., 2011; Ovink, 2014). While it is beyond the scope of this literature review to extensively explore each of these factors, it is important to highlight that traditional college choice models (i.e., Hossler and Gallagher's [1987] predisposition, search, and choice model) have not been inclusive of the role families in the college choice process, although as demonstrated, familiasm and familismo play key roles in Latina/o college decision-making.

As discussed, Latina/o students are overrepresented at proprietary institutions. Thus, it is important to turn our attention to the role of such institutions. In doing so, we review the few studies that offer research on the connections between Latina/o college student enrollment patterns, factors, and proprietary college choice.

\section{The role of proprietary institutions}

One of the most rapidly growing areas in higher education is the for-profit sector, also known as proprietary, vocational, or trade institutions (Weisbrod, Ballou, \& Asch, 2008). Referred to as "innovators" by Tierney and Hentschke (2007), proprietary institutions account 
for approximately $23 \%$ of higher education institutions, enrolling over $6 \%$ of all students, although this does not account for for-profit institutions that do not grant degrees (Weisbrod et al., 2008). The growth of proprietary institutions was especially rapid in the 1970 s, when federal financial aid in the form of Pell Grants, were first awarded (Weisbrod et al., 2008). However, over 100 proprietary institutions exist that can track their origins back over a century (Kinser, 2006.

Customer-student service is arguably the key factor in for-profit higher education institutional success. The for-profit model invests in student/customer services, which includes classes that begin on a frequent basis, accessible parking, and convenient course locations and times (Weisbrod et al., 2008). Likewise, offering students skills and training for specific jobs and assistance with job placement is also a benefit (Tierney \& Hentschke, 2007). Such job specific training is available because curriculum is often "co-produced" by the proprietary institution and local employer representatives, with instructors representing those same employers (Tierney \& Hentschke, 2007, p. 111). Finally, because a typical proprietary model does not include the opportunity for many elective courses, students receive structured and career-focused programs of study (Tierney \& Hentsche, 2007). The non-traditional demographics of students at proprietary institutions are the most employed rationale that for-profit supporters offer with respect to the major benefits they add to American higher education (Bagnato, 2004). These institutions are providing more access to low-income, Black and Latina/o groups at higher rates than their not-for-profit counterparts (Bagnato, 2004; Hayes, 2012).

Proprietary institutions have managed to substantially narrow the Black, Latina/o, and American Indian college enrollment gap (Bagnato, 2004), a feat elite and research universities have continually struggled with (Astin \& Oseguera, 2004; Perna, 2000). Research exists that 
points to reasons accounting for the narrowing of this enrollment gap: (1) program and course flexibility due to the online nature of most institutions, (2) minimal selectivity in admission requirements, (3) high proportion of expenditures on marketing and recruitment, and (4) corporate and industry investment in employee training and skill advancement (Hayes, 2012).

Oseguera and Malagon's (2011) study on proprietary institutions and Latina/o students focused on the attributes that characterize Latina/o students at these institutions, and the factors that contribute to their eventual enrollment at a proprietary institution. The study's sample consisted of 2,112 Latina/o students enrolled in proprietary institutions across the country, drawing from the NCES Educational Longitudinal Study's (ELS) 2002-2006 survey data (Oseguera \& Malagon, 2011). Findings from this study revealed that online marketing and negative high school educational environments increased the likelihood that Latina/o students would enroll in a proprietary institution. It is not common to find data on Latina/o student enrollment at proprietary institutions disaggregated by gender. Oseguera and Malagon (2011) offer one finding that illustrates, "a Latina's odds of enrolling in a 4-year for-profit campus increase but decrease in a 2-year campus" (p. 83). This is important to note as it disputes research that suggests men are more likely to enroll in a for-profit institution (Oseguera \& Malagon, 2011). Cottom's (2017) extensive study of the for-profit sector also finds that social inequality is the major factor fueling this sectors' growth and "their long-term viability depends upon acute, sustained socioeconomic inequalities" (p. 21). The structures influencing the appeal of these institutions for low-income Latina students in urban schools and residential settings have yet to be comprehensively understood from an intersectional race, gender, and class perspective.

\section{Conceptual Framework}


We employ a conceptual framework that draws from Chicana feminist epistemology, which intersects how white supremacist capitalist oppression has contributed to the social, political, and economic conditions of Chicanas. These conditions not only pertain to Chicanas but to women of color broadly. Bernal (1998) states, "I draw from the strong traditions of Black, Native American and Chicana feminists" (Bernal, 1998, p. 556). Here Bernal (1998) provides support for drawing from women of color scholarship that crosses racial/ethnic categories. Chicana Feminist Epistemology is informed by Endarkened Feminist Epistemologies (Dillard, 2000), and both are paradoxical to our western associations of science and western research traditions as light and enlightening. Endarkened feminist epistemology centers the voice and experiences of women of color (read: dark) and their resistance to continued underrepresentation and misrepresentation in western research (read: light). In essence, although education systems broadly have been conceptualized as enlightening and necessary in economic western upward mobility, it is a fallacy when considering the growing wealth gap between marginalized groups of color and dominant white groups in the west. These cross-sectional traditions of women of color challenging domination influences our rationale in using Chicana feminism to explore the college choice decisions of Latina students.

The lives of Latina youth are heterogeneous, and how college choice studies conceptualize "college" and "students" typically takes root in scholarship grounded on epistemological racism (Schuerich \& Young, 1997). Bernal (1998) explored working-class Chicana student narratives, just as we explore low-income Latinas who live in urban areas suffering from urban decline. Chicana Feminist Epistemology (CFE) has a focus on the personal oral histories of Chicanas and assists in unpacking data on the lived experiences of raced, gendered, and classed women and girls from Latina/o backgrounds. Chicana feminism 
“addresses immigration, migration, generational status, bilingualism [and] limited English proficiency" (Bernal, 1998, p. 561), which are western concepts with binaries that position Latinas on the negative sides of each of these dichotomies.

In using a Chicana feminism approach we interrogate the concept of student markets within the framework of academic capitalism (Slaughter \& Rhoades, 2004). Academic capitalism is a system of oppression that intersects with racist and sexist understandings of college choice. Chicana feminism applied to the possible channeling of low-income Latina students' college choices questions the assumption of choice rather than institutional targeting. "Academic capitalism in the new economy involves institutions turning toward students as targets for the extraction of revenue, including but extending beyond tuition" (Slaughter \& Rhoades, 2004, p. 279). Our symbol of the dangling carrot is the mirage of college choice that proprietary institutions hang in front of low-income Latinas. This mirage and attraction to the proprietary institution may be influenced by social constructs of race, gender and class and are more specifically related to academic capitalist shifts in higher education recruitment. "As institutions adopt more of an economic, proprietary orientation to students, the consumption versus the educational dimensions of a college education becomes emphasized" (Slaughter \& Rhoades, 2004, p. 279). Therefore, having implications on how Latina students may be positioned as second-class markets.

Chicana feminism assists in contextualizing the Latina student market within the broader culture of U.S. consumption, which addresses contradictions in consuming behaviors of marginalized groups. In our study this relates to the consumption of higher education. Davila (2012, p. 22) argues that: 
U.S. consumer culture has long documented the ways in which consumption by marginal groups in society, be they Black, Latino or women is pathologized as abhorrent, irrational and out of control, in reference to an imagined rationale consuming subject who is thrifty, savvy, and immune to the seductions and deceptions of the market.

With respect to how Chicana feminism applies to our analysis, we argue that proprietary institutions play a role in what appears to be a pathologizing of Latina youth as consumers of their product. We argue that the draw for Latina students to choose proprietary institutions although they are financially unviable is related to their racialization (Montoya, 2006) and classed position, which lead to skewed perceptions of their consumer behavior (Davila, 2012) by such institutions. The symbolism of what low-income (synonymous with urban) students of color represent to the higher education community may be influenced by perceptions of their consumer behavior as nonsensical and uninformed (Davila, 2012) and is situated within capitalist, racist, and sexist domination. Latina student experiences are intersectional (Crenshaw, 1991), and our study addresses their college choice decisions from a race, class, and gender perspective. Crenshaw (1991) states of intersectionality, that "the experiences of women of color are frequently the product of intersecting patterns of racism and sexism... these experiences tend not to be represented within the discourses of either feminism or antiracism" (pp. 1243-1244). Although Crenshaw's (1991) theory of intersectionality is not all encompassing, she does mention that class and sexuality are systems of oppression that work in tandem with race and gender for women of color. Bernal (1998) brings in a class lens and Chicana feminism allows us to explore further how local low-income Latina populations are positioned as vulnerable markets and consumers rather than student learners, which contributes to an environment of inequality and oppression. 


\section{Methodology}

In employing a Chicana feminist framework, our methodology is grounded in sociopolitical and ethical considerations of Latina student local college choices. As three women of color researchers: the first-author identifies as Afro-Cuban, the second author identities as Mexican-American, and the third author identifies as African-American, our research positionalities similarly align with that of our participants along race and gender lines. Within a Chicana Feminist Epistemology, Bernal (1998) describes cultural intuition as closely aligned with theoretical sensitivity which is comprised of "four major sources: one's personal experience, the existing literature, one's professional experience, and the analytical research process itself"' (p. 563). As such, the data analyzed through a Chicana Feminist lens draws on our unique researcher positionalities as women of color who too have navigated the educational pipeline in urban and rural school settings.

The present study is a follow-up to a larger study conducted at an urban school district in New York State. Dache-Gerbino also attended this school district as an AfroLatina student for her entire elementary and secondary school years, which supports Chicana Feminisms' cultural intuition of Latina scholars investigating Latina students. We drew a sample of 16 Latina students from the original study in which 95 students, ages 11-18, and 41 parents / guardians participated in 31 bilingual focus groups across the local community. The purpose of the original study was to examine the barriers that prohibit Latina/o students from successfully progressing through K-12 schooling. A significant finding from these original focus groups related to the structural, external (outside of school), and neighborhood factors impacting schooling for urban Latinas. We were interested in how external factors of access were related to Latina college choice paths, a topic we were unable to explore in depth in the focus groups interviews. Thus, we 
returned to our original sample of 95 students to identify which of these students fit our criteria of identifying as Latina and fell within a college-choice or enrollment process. This led us to a sub-sample of $20,10^{\text {th }}$ grade through college-going Latinas. Of these 20 Latinas, 16 accepted our invitation to participate in individual interviews.

This follow-up study with 16 urban Latinas is informed by sequential mixed-method models (Creswell \& Clark, 2011), yet our design consists of qualitive and geographic data, solely. The sequential nature of this geographic design relied on collecting the qualitative data first, which then informed the geographic data collection and drove the inquiry into the geographic and qualitative analysis. The geographic phase of the study incorporates Geographic Information Systems (GIS) in order to provide residential data on the geographic space of the Latina sample residential area. Collecting the geospatial data after the qualitative portion of the study supports our theoretical connections of racism, gender, and class oppression facing Latina students and the sociospatial factors of the environment surrounding them. Our geospatial data results align with the results of our qualitative analysis, which is evidence of the intersectional relationship of class, race, and gender with space and place. The geocoded data is evidence of Latina/o residential segregation and class segregation and its relationship to the college choice experiences of Latina students who reside in these geographic areas.

\section{Data Sources}

We invited 20 Latinas out of the original 54 who participated in the focus groups to participate in individual interviews. As noted, in this phase of the research we focused specifically on sophomores, juniors, seniors, and recent graduates since we were interested in the collegegoing paths, neighborhood, and socio-spatial college access factors influencing Latinas higher education opportunities. Sixteen Latinas were interviewed, providing an $80 \%$ response rate. 
Our sample of 16 Latinas included $10(62.5 \%)$ who identified as Puerto Rican, two (12.5\%) Dominican, one (6\%) Cuban, two who did not identify (12.5\%) and one multi-racial Latina (6\%) (see Table 1). Two of the young women had graduated high school and were either enrolled in or planning to enroll in proprietary institutions. Six of the Latinas were in 12th grade, four of whom indicated they intended to enroll at the local community college, one who indicated she was intending to apply to culinary school after taking a year off and one who was awaiting notification from the private four-year institutions she had applied to. Four of the Latinas were in 11th grade, and their college aspirations included attending the local community college, proprietary institutions, and private four-year institutions. Finally, four of the Latinas were in 10th grade, and all had aspirations of attending a four-year college. All Latinas and any institutions referenced within their following quotes have been assigned a pseudonym.

Table 1: Latina Sample with College Choices

\begin{tabular}{|c|c|c|c|c|c|c|}
\hline Name & High School & Grade & Race / Ethnicity & Aspirational College & Colleges Applied To \& Type & $\begin{array}{l}\text { Current College Choice and/or } \\
\text { admitted to }\end{array}$ \\
\hline & & & & & & half semester at County \\
\hline & & & & & 3 private 4 -year and 1 & Community College (CCC) - \\
\hline Elena & Mendez & Graduated & Puerto Rican & proprietary & community college & (currently) \\
\hline Damaris & Mendez & Graduated & Did not identify & proprietary & 2 proprietary & proprietary \\
\hline \multirow[t]{3}{*}{ Alyssa } & Mendez & 12 & Puerto Rican & private 4-year & 4 public 4-year & $\mathrm{CCC}$ \\
\hline & & & & & 3 private 4-year & \\
\hline & & & & & 1 community college & \\
\hline \multirow[t]{2}{*}{ Julia } & Mendez & 12 & Dominican & private 4-year & 1 private 4-year & not yet notified \\
\hline & & & & & 1 public 4-year & \\
\hline Marissa & Elliott & 12 & Puerto Rican & community college or Army & not yet applied & \\
\hline Lupita & Fountain & 12 & Puerto Rican & community college & 1 community college & $\mathrm{CCC}$ \\
\hline Alma & Fountain & 12 & Did not identify & community college & not yet applied & \\
\hline Jessica & Mendez & 12 & Puerto Rican & culinary school & not yet applied & taking year off for work \\
\hline Sonia & Mendez & 11 & Puerto Rican & proprietary & & \\
\hline Maria & Wagner & 11 & Cuban & private 4-year & & \\
\hline Alicia & Elliott & 11 & Puerto Rican & community college & & \\
\hline Dora & Elliott & 11 & $\begin{array}{l}\text { Puerto Rican, } \\
\text { Mongolian, Indian }\end{array}$ & private 4-year & & \\
\hline Carla & Mendez & 10 & Dominican & veterinary school & & \\
\hline Kira & Mendez & 10 & Puerto Rican & private 4-year & & \\
\hline Gabriela & Mendez & 10 & Puerto Rican & private 4-year & & \\
\hline Victoria & Mendez & 10 & Puerto Rican & Army & & \\
\hline
\end{tabular}


We utilized geographic data to provide a socio-spatial understanding of the residential conditions contextualizing our qualitative findings. In the geographic portion of this study, we used census data derived from the American Community Survey (ACS) (U.S. Census Bureau, 2010), and state and county geographic data in order to provide a visual analysis of the socioeconomic, racial/ethnic socio-spatial factors contributing to Latina student experiences related to proprietary institutional choice by Latina students.

\section{Data collection and analysis}

Qualitative Interviews. Interviews were open-ended, but were guided by an interview protocol (Bogdan \& Biklen, 2007). Interviews were conducted in either English or Spanish, depending on participants' preferences. Researchers conducted interviews at students' schools, in community libraries, and in their homes. The interview protocol was organized into sections related to educational experiences, college-going, and college navigation. First, we asked about Latinas' current educational experiences and future educational goals. We were interested in where they aspired to attend college, where they applied to college, and where they had been accepted and/or attended. Because violence was brought up as a topic during the original focus groups that the Latinas participated in (see Kiyama et al., 2016), we focused the second section on the role of violence in school. However, this section was not used for analysis for this particular paper although proprietary institutions targeting low-income students for financial incentives - is a form of symbolic violence (Kiyama et al., 2016). Finally, we focused on the individual and social structures involved in the Latinas' navigational processes into college. We were particularly interested in how college opportunities were formed and manifested.

For the purposes of this study, we focused qualitative data analysis on how Chicana feminism explains the intersections of proximity, recruiting and marketing, finances and cost, 
and influence of family on Latina student college choice. Since our study evolved from previous data, this coding technique fit our current body of data best. Layering this secondary analysis with the theory of Chicana Feminism (Bernal, 1998) allowed us to further interrogate themes around racism, sexism, and classism and their relationships with marketing and consumption of higher education for local urban Latina students.

Geographic Mapping. Using Chicana feminism calls for inquiry of external sociospatial influences surrounding our Latina sample due to how the location of colleges are shaped by the history of residential segregation (Dache-Gerbino, 2016). Socio-spatial data and analysis were critical to extending our qualitative findings related to race, income, and geography. Geographic data collection happened through the use of ArcGIS mapping software. We used the following datasets from the American Community Survey (ACS), 2010 5-year estimates: (1) Income in Past Twelve Months (Adjusted for inflation) and (2) Demographic and Housing Estimates (U.S. Census Bureau, 2010). In addition, we used state (New York State GIS Data Clearinghouse, 2012) and county (County Geographic Information Systems, 2011) geographic shape files for county and city boundaries and college locations. The findings of the qualitative data were enhanced by geographic findings of varying types of institutional college locations, racial/ethnic and socioeconomic factors.

Our methodology and critical geographic analysis aligns well with our Chicana feminist framework. "Employing a Chicana feminist epistemology in educational research thus becomes a means to resist epistemological racism and to recover untold stories" (Bernal, 1998, p. 556). This is evident in the qualitative and geographic methods used concurrently to collect and critically analyze data centered on the racialized and gendered educational experiences of Latinas in urban schools. 


\section{Findings \& Discussion}

We present two major findings from the data related to the appeal proprietary institutions have on Latina students and its relationship to Latina racialization in student educational markets. The first finding is (1) the location of proprietary institutions ${ }^{3}$ and their proximity to the Latinas' residential area. This first finding is further supported by the following two subfindings: (a) Proprietary recruitment strategies and marketing appeal, and (b) Latinas' living in the sample areas facing financial constraints attending a local proprietary institution. The last finding (2) reveals the relationship students' grade-level in school has to their draw to local forprofit institutions, revealing how proximity, recruitment and marketing influence college choices as Latina students enter higher grades.

\section{Location of Proprietary Institutions \& Proximity to Latinas' Residences}

The distance of post-secondary institutions to students' homes is a significant part of the college choice process (Turley, 2009). Location and proximity to student markets from a proprietary institutional perspective also reveals that proprietary institutions follow population density (Chung, 2008). As previously noted, states like New York with high population density also have the highest proportions of proprietary institutions. In addition, for-profits were located in urban areas or on the borders of urban and suburban areas close to shopping plazas and highways (Chung, 2008). In our first major finding, Latinas' college-choice decision-making process was driven by proximity to their home. Some Latina students revealed that they preferred not to travel for college and wished to stay close to home, which, as we covered above, is supported by literature on Latina college choice. In the first example, Elena shares how NYU sent her an informational package, but she was not interested in the expenses associated with attending away from home and was interested instead in attending a for-profit institution that was close to her home: 
It was basically saying what they [NYU] wanted, like why they wanted me to go there ...But like I was like I'm not going to like go all the way down there cause it's really expensive in New York, especially to get an apartment and all that, but I don't want to move all the way down there just to go study and all that.

Elena, high school graduate

Here Elena presents the idea of "going to" college as a process of going away from home. She clarifies that her college plans are a culturally bound concept given her desire to stay closer to home. The most recent studies on proximity within college choice are specific to distance from home and explore how spatiality plays a major role in structuring educational opportunities for students (Goble, 2010; Turley, 2009). Most of these studies used proximity as a variable in statistical models in order to test if college distance played a major role in applying to and enrolling in college. Yet, researchers lacked a Chicana feminist understanding of how these factors related to low-income and Latina/o student recruitment and market targeting. Since the increase of proprietary institutions in metropolitan areas is due to target marketing (Fisher, 2012), low-income populations who are less likely to go away to college (Goldrick-Rab, 2006) and are concentrated in urban areas are part of these targeted efforts.

In addition to these geographic specific contexts, living near parents was also a factor in where students chose colleges, since students were narrowing their choice due to their preference to be near family (Turley, 2006). This is particularly true for Latinas who often wish to remain close to family because of both family obligations and family support (Sapp et al., 2016; Sy \& Brittian, 2008). Although Carla was only in $10^{\text {th }}$ grade at the time of the study, she too expressed concern in moving away from family.

Carla: I was thinking about [veterinary institution] but that's three hours from here and that's too much gasoline, I don't know. 
Interviewer: Would you consider living there?

Carla: I would but I don't want to be separated from my family. I don't know. One of the tensions found in this study rests in the educational options that Latinas perceived were available to them with respect to proximity to home. A common sentiment regarding college options expressed by most of the participants was, "They're too far." Therefore, the farther you lived from a college, the less likely you were to attend college (Rouse, 1995). While it may appear on the surface as stereotypical gender roles in the home, we argue that Latinas made an active decision to balance and fulfill both family and academic roles (Sapp et al., 2016; Sy \& Brittian, 2008). In these cases, Latinas both offered and gained support from their families and communities. Both Lupita and Maria exemplify this decision when describing her familial obligations:

I clean the kitchen, I have to feed my sister. Sometimes if there's meat out I would cook dinner so my mom wouldn't have to do that much stuff. Future obligations that I think about - you know, what if my sister is sick from school? My mom and my dad might not be able to pick her up. If I don't have class, you know, I could go do it or she needs to be taken to the doctors you know, I would do that. ${ }^{4}$

Lupita, high school senior

Considering similar family obligations, Maria (a high school junior) stated:

Maria: and me having a lot of responsibility at home, like I translate always for my parents and I'm like their secretary and it's just a lot of things... then also the time it would cost me [remaining in extracurricular activities] - to drop out from it was we had a store, a small business which I had to like help out in

Interviewer: So family obligations have a lot to do with what you're able to do academically?

Maria: Right. 
Cammarota (2004) suggests Latinas face the challenge of "managing the contradiction between gender advancement through educational attainment and the preservation of gendered cultural norms" (p. 55). In working to balance such expectations, Latinas in this study push back against notions that suggest these identities must exist independent of or in opposition with one another. Latina students also wanted to attend proprietary institutions due to their accessibility in relation to transportation.

I liked more Jefferson (proprietary institution) but Eastern Institute was closer, Jefferson is all the way in Hellenville [a suburb of the City of Ridgewood] so because of the transportation it was easier for me.

Damaris, high school graduate

Damaris was referring to utilizing the public transportation system as a means to attend college. Likewise, in the quote above, Carla also addressed issues of transportation as she expressed concerns about the amount of gasoline needed to travel to college away from home. Thus, it is imperative to understand that both Latinas reference concerns not only about the act of getting to their respective colleges, but the cost of doing so. When considering the larger structures that limit college opportunity for low-income students, inadequate public transportation becomes a significant urban-related factor (Dache-Gerbino, 2017).

The GIS results extend our qualitative findings and reveals that proprietary institutions and a community college were the closest in proximity to the Latina sample. In the City of Ridgewood and its fringes, proprietary institutions were closer to the Latina sample residence area than four-year institutions (see figure 1). Given the national profile, and increase in Latina/o population, these institutions' close proximity to the Latinas is connected to targeted markets and student populations that are likely to attend these types of institutions. 
Moreover, our GIS results illustrate that these institutions were located on the urban fringes of the City of Ridgewood. The placement of proprietary institutions surrounding lowincome, urban areas may suggest a placement and location strategy aiming to target students as uninformed consumers. Furthermore, what is not mentioned in previous studies regarding the locations of proprietary institutions are their proximity to low-income areas and urban areas with the highest Black and Latina/o populations. We discuss these factors in the findings that follow.

\section{Figure 1: College Location Map and Latina Student Residential Area}

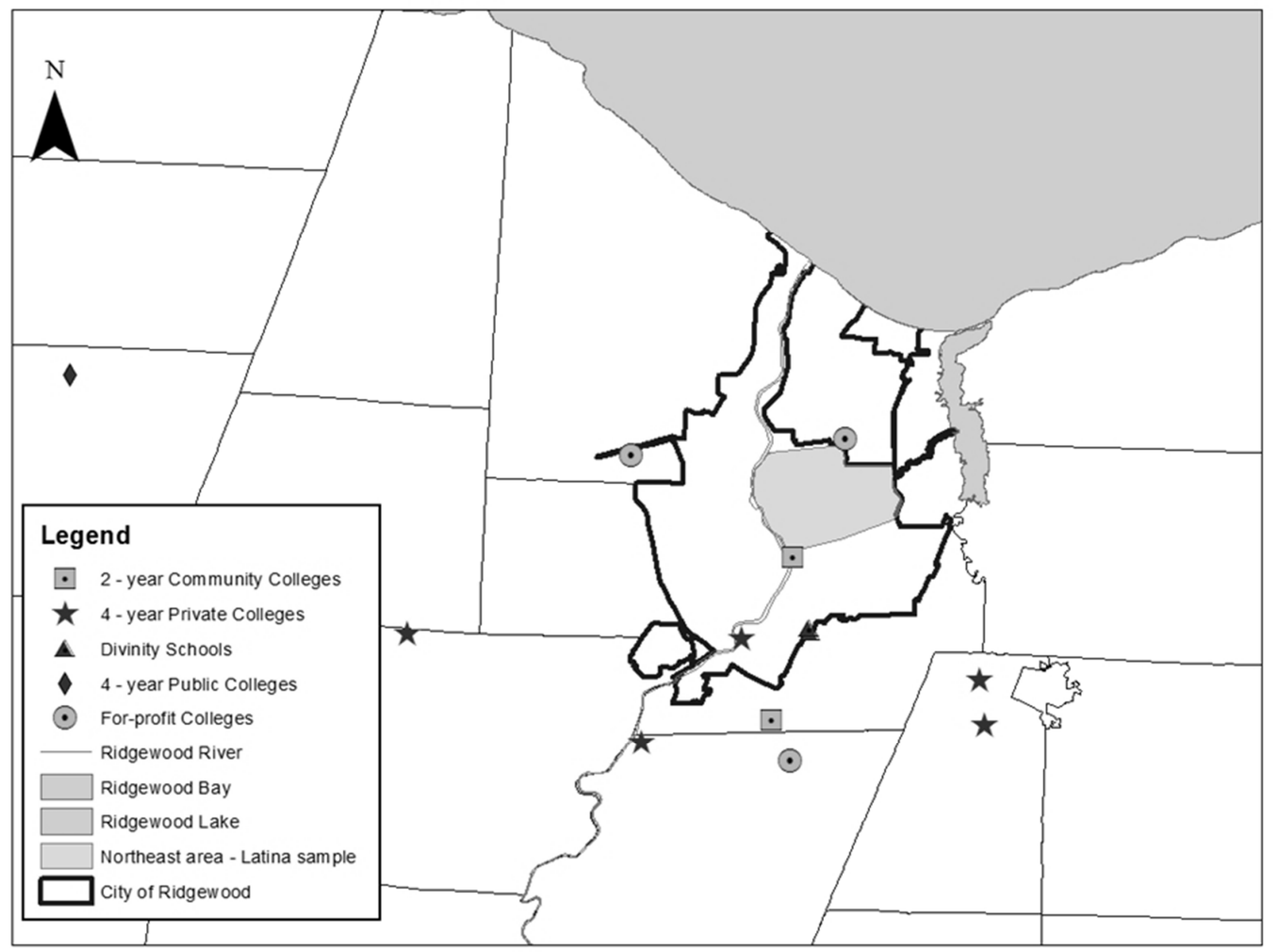

GIS data also reveal that when mapping census tract level data specific to the numbers of Hispanic/Latina/o county residents living within and surrounding the City of Ridgewood, the 
Latina sample area had the highest numbers of Latina/os in the City of Ridgewood (figure 2). If proprietary institutions are closest to the highest Latina/o populated areas, proximity functions as a factor limiting opportunity.

In figure 2, the City of Ridgewood is indicated by the outer dark line. It is clear that the highest proportion of Latina/os reside within the City of Ridgewood, indicated by the mostly densely shaded areas. Then, when looking within the City of Ridgewood, the smaller outlined area indicates the neighborhoods in which our participants resided, also densely shaded and bordered by a proprietary institution and a branch of the local community college.

Figure 2: College Location Map, Latina Student Residential Area and Hispanic/Latina/o

\section{Population}

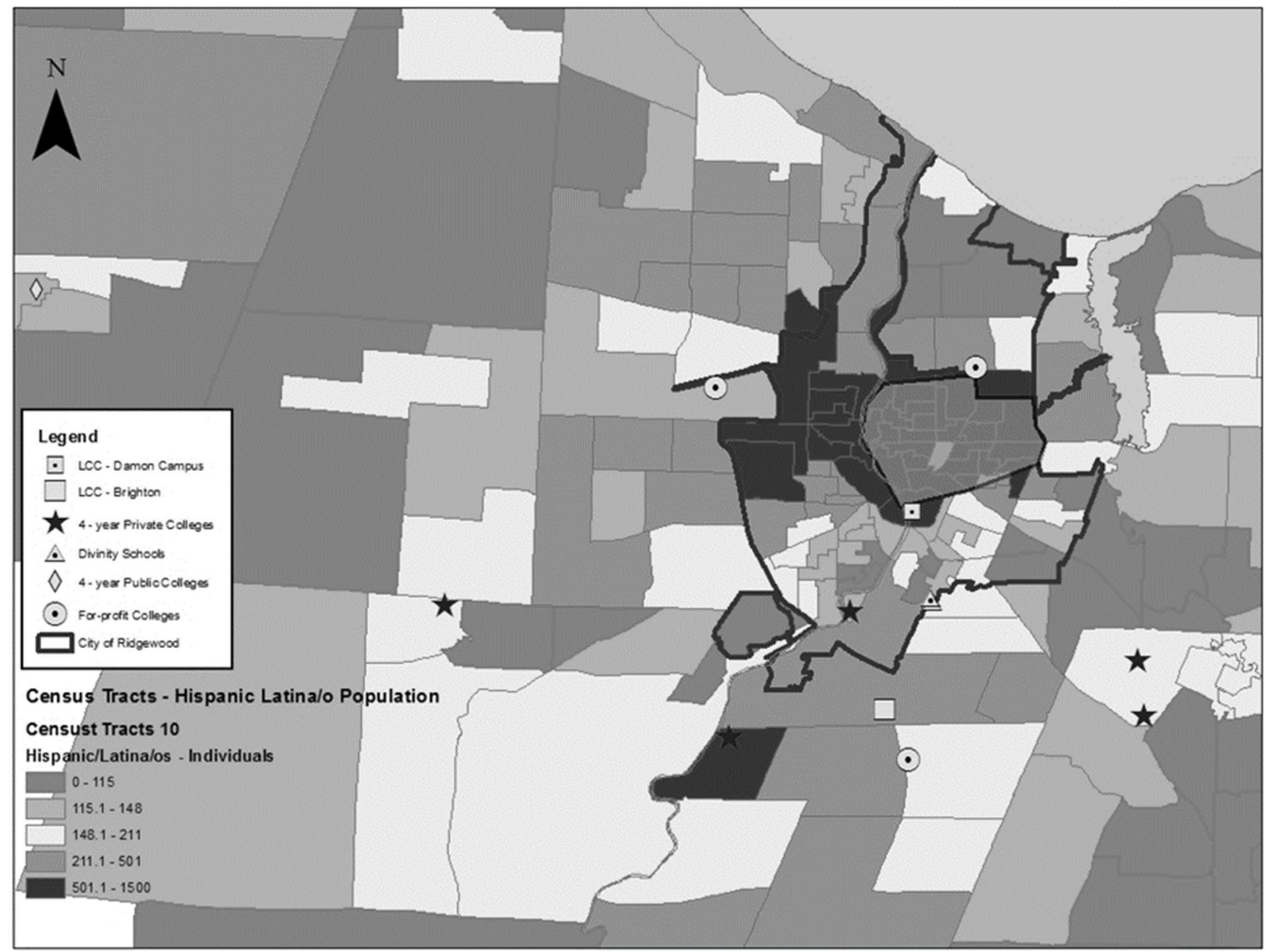




\section{Proprietary recruitment strategies: Selling vocational programs as a dangling carrot}

Latinas shared that local proprietary institutions frequently recruited at their high schools and led them to believe that certificate and vocational programs were better than liberal arts focused degree programs. These Latinas believed that liberal arts focused degrees or nonvocational track degrees were not going to assist them in finding immediate employment in their area of interest. As shared by Sonia, attending a "school of beauty" (a for-profit institutional type) was already like being in a job:

But like in [school of beauty] it's like a job type thing, you punch in, you punch out... It's like a fast thing to do other than stay in college and four years of something. For me like I like a short period, it's like 8 months and that's it.

Sonia, high school junior

The high schools these Latinas attended are predominantly low-income, have high Latina/o student populations, high dropout rates (36\%), low graduation rates (38\%), and offer bilingual programs. Such recruitment occurred in spite of the tuition for these institutions being financially unviable for students. In fact, Sonia shared that she was struggling to find the registration fees to apply and was waiting until her father could afford the fee. When asked why she decided on this particular school versus another cosmetology school Sonia responded,

If I go to [another cosmetology school] I'm supposed to like pay the money up front, like I think it's like $\$ 700$ something for the books. I have no job, I'm not going to go ask my parents for that kind of money when they have to pay bills and all that and in [school of beauty] you pay six months after you graduate and you get your everything, so for me I think that was better because in 6 months I know I'll have a job or something here. 
Sonia's quote indicates that she has made her decision based on an expectation of gainful and swift employment after graduation. The next two quotes from Damaris illustrate her rationale for choosing a proprietary institution because it served a concrete, employment function.

Eastern Institute... would come to our school, people from Eastern, and talk and what not, and I was always interested in Eastern and Jefferson Institute, because of the reason that you go directly to study what you want. [Local Community College (LLC)] ...you don't start to study the things that you really need for the major that you want.

So I always said, I don't go to LCC to waste time, that doesn't go with me. I don't want to dorm, nothing like that I want to do my career and get over with. So I always had in my mind Eastern and Jefferson.

Damaris, high school graduate

Similarly, Elena expresses frustration with the requirement of taking liberal arts courses at the local community college as she believed they were not directly related to her future employment aspirations.

They [LCC] were putting me [in other classes] like I wanted pre-law, to be in law school, the problem is they didn't have that program so they put me in political science instead, in liberal arts and everything but like it's taking forever just to get the [class], like they don't give you the class that is specifically for that, they just give you another class. Like I understand we need math and English but like I want like [pre-law classes].

Elena, high school graduate

Damaris and Elena expressed that they preferred to take courses specific to their employment goals instead of more liberally oriented courses. Although vocational programs are a post-secondary option, Damaris' and Elena's rationale for choosing job-specific courses, rather 
than liberal arts, pre-professional program-oriented courses, supports the false assumption that liberal arts courses are not needed in the workforce (Gardner, 2006). Elena's example also suggests that there was a lack of understanding about the type of courses required for a pre-law undergraduate program. Although proprietary institutions are providing college accessibility to low-income students who have minimal access to local four-year institutions, it is to the Latinas' detriment to enroll at a proprietary institution due to their expense and to their job-related specific curriculum. The Latinas in our study experienced the recruitment by for-profit institutions as dangling carrots. We utilize the image of the dangling carrot, which represents the expectations that participants have created based on incomplete information about future employment, tuition and fees, and required coursework.

Again, we look to the structures within the educational system - college preparation and academic advising that could have provided the academic counseling necessary for Elena to be knowledgeable about a pre-law degree program. One must also question if the marketing practices employed by proprietary institutions plays to this lack of knowledge, promising a rapid employment picture with local businesses upon finishing an equally rapid degree program. Because of this production and consumption thinking that aligns with the local corporate and business sectors that partner with proprietary institutions, students translate into targets of revenue extraction (Slaughter \& Rhoades, 2004) influenced by the systemic race and class oppression of Latina women (Bernal, 1998).

In addition, a study of the characteristics of proprietary institutions found that, "if students report obtaining information about college from websites and college representatives, the odds of enrolling at a 2-year for-profit increased" (Oseguera \& Malagon, 2011, p. 83). Likewise, media images have an impact on Latina/o student college and career choices 
suggesting an external racist and sexist cultural influence (Bernal, 1998) of how Latina/os are portrayed in commercials and television programming (Alvarez, 2010). As illustrated below, this was the case with Latinas in this sample. Although technological advances are a sign of economic progress, our findings suggest that the college opportunities of Latinas were being structured by marketing geared to faster and job related degrees.

Like you know it's Nag Job [an online proprietary search company] or something that, like okay I want to go back to college and continue school and all that, then they call me up and they be like I have to give them my zip code and they'll see what school is around that has criminal justice in that field. They told me Kaplan University, Eastern Institute [local proprietary institution], American Intercontinental but like that's the Internet one, and I don't remember the other one, Stayer University.

Elena, high school graduate

At this point in the interview the researcher clarified that all four institutions Elena mentioned were online schools, "So those are all online colleges, you know that right?" To which Elena responded vaguely, "mmm hhmm." Her response differed from what she stated above in that only American Intercontinental was the "internet one." Campbell and Deil-Amen (2012) suggest online aggressive recruitment "may begin with a prospective student requesting more information from a website. Immediately the college aggressively pursues the student, rather than the student pursuing the college" (p. 8). Elena appeared unclear about the types of institutions she was being directed to. If Latinas are being deceived (Davila, 2012) by the marketing, recruiting, and commodifying behaviors that proprietary institutions engage in and are being positioned as uninformed consumers, an environment of educational inequity is perpetuated. 
The customer-service like approach of for-profit institutions is related to their spending allocations on student services (Hayes, 2012). Some studies found that fewer institutional funds were being allocated for instruction, but more money was being allocated in student services, which have an influence of student recruitment and outreach efforts (Hayes, 2012). Thus, the "carrots" used for marketing and recruitment are well developed and well funded. Marketing to Latina students as clients rather than learners can be understood through our framework of Chicana feminism as such practices highlight the deficit-centered symbolism of low-income Latinas as irresponsible consumers (Davila, 2012).

\section{Financial constraints on Latina students attending a proprietary institution}

The literature on proprietary institutions supports our findings that Latina students attending proprietary institutions mirror the national student social, labor, and economic characteristics. Chung (2008) describes the characteristics of students at proprietary institutions as more likely to have dependent children, be single parents, be financially independent, and either have a full or part-time employment. The following Latina narrative reveals how difficult attending a proprietary institution can be on low-income students living in close proximity to proprietary institutions.

This year...even though I am working, it has been difficult for me to pay my rent, pay the electric, buy baby's diapers, and basically support us. It has been difficult and challenging.

She continued,

Last month I fell into a depression, because my spouse had to work in Charleston, which was 3 hours away from here. So I was alone with the baby and it made things very difficult not having any help from him. 
Damaris, high school graduate

Damaris, who lived less than a mile from the proprietary institution she attended, shared that although she persisted to high school graduation while nine months pregnant, she felt her only option was a vocational nursing assistant aspiration at the closest proprietary institution to her home, Eastern Institute. Therefore, in trying to provide economically for her daughter and herself, she was determined to attend this local proprietary institution while working at a clothing store. She stated that the cost for her to attend this institution was the following, "The total of everything was $\$ 18,000$ and so...For the whole degree, everything." Damaris further explained that the above cost included textbooks, a nursing uniform, a stethoscope and medical assistance tools. Although Damaris shared that she believes this cost to be expensive, she also believed that Eastern Institute is her best option in obtaining a job in order to provide for her family, a "very big opportunity" as she described below,

They [the proprietary institution] tell you that they don't promise you a job after you finish, but they help you. I started in October, they still haven't given me the training in a hospital, but I already had my class in lab, medical lab, and I know how to take the blood pressure and things like that, but right now I have a very big opportunity.

In order to understand how socio-spatial factors can extend Damaris' narrative, using a GIS method, we mapped the 12-month household income data for the lowest income category of less than $\$ 10,000$ a year (figure 3) across the City of Ridgewood and the surrounding county. The results revealed that the Latina sample area had the highest number of households within the category of earning less than $\$ 10,000$ a year. This finding is significant since students from lower SES homes are less likely to leave home for college (Goldrick-Rab, 2006). Similarly, we mapped the 12-month household income data for the highest income category of more than $\$ 200,000$ a 
year (figure 4) to compare what colleges were closest in proximity to the wealthiest areas in the county. The results of this GIS method revealed that the Latina sample area had census tracts with the lowest number of households with incomes of $\$ 200,000$ or more. Interestingly, the closest post-secondary institutions to the Latina sample area were two proprietary institutions and a community college branch campus. However, higher income areas in the county had diverse post-secondary options in close proximity, especially in the southeast portion of the county.

Figure 3: College Location Map, Latina Student Residential Area and Estimation of the Number of Households per Census Tract Earning Less Than \$10,000

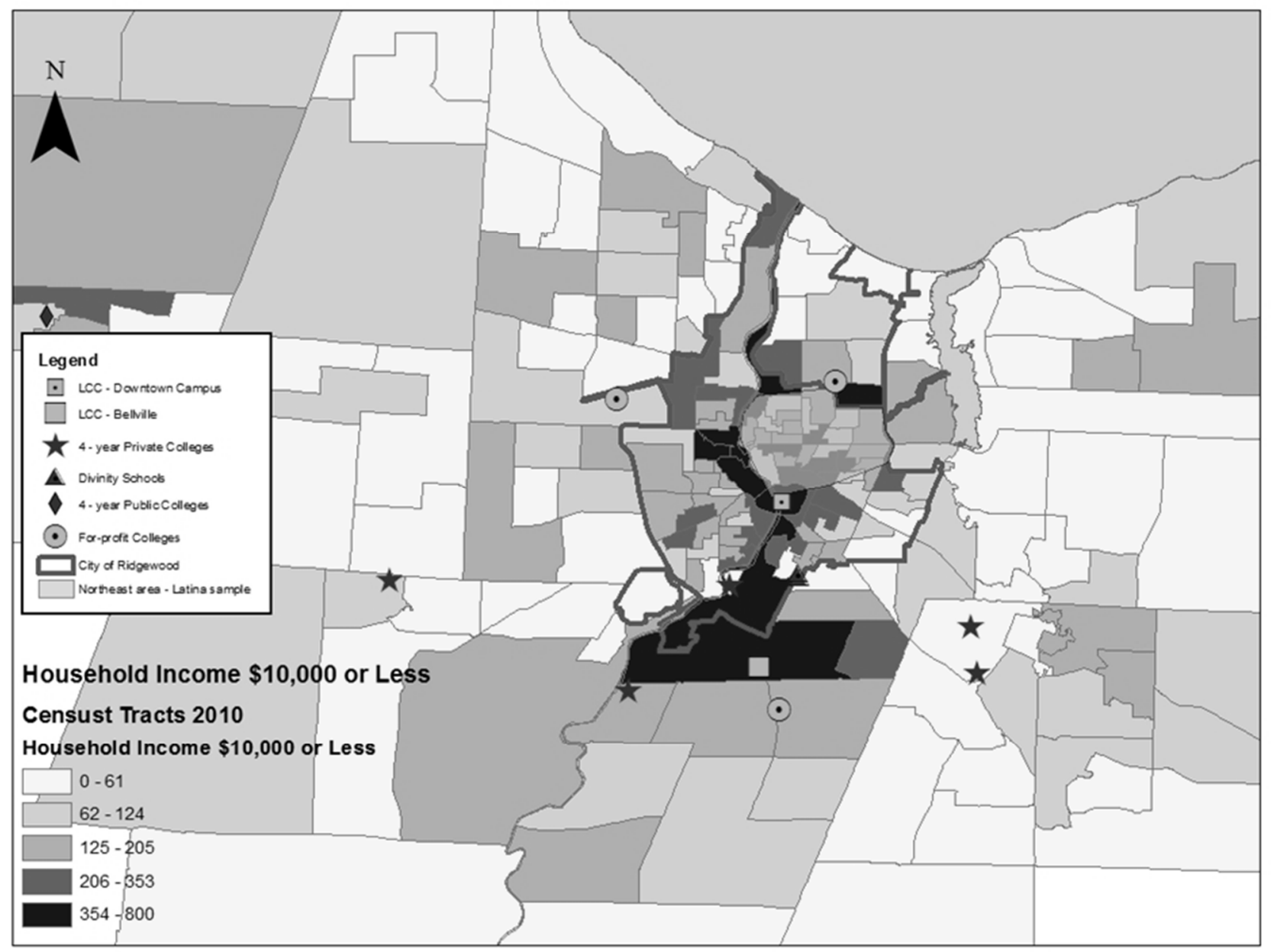


Figure 4: College Location Map, Latina Student Residential Area and Estimation of the Number of Households per Census Tract Earning More Than \$200,000

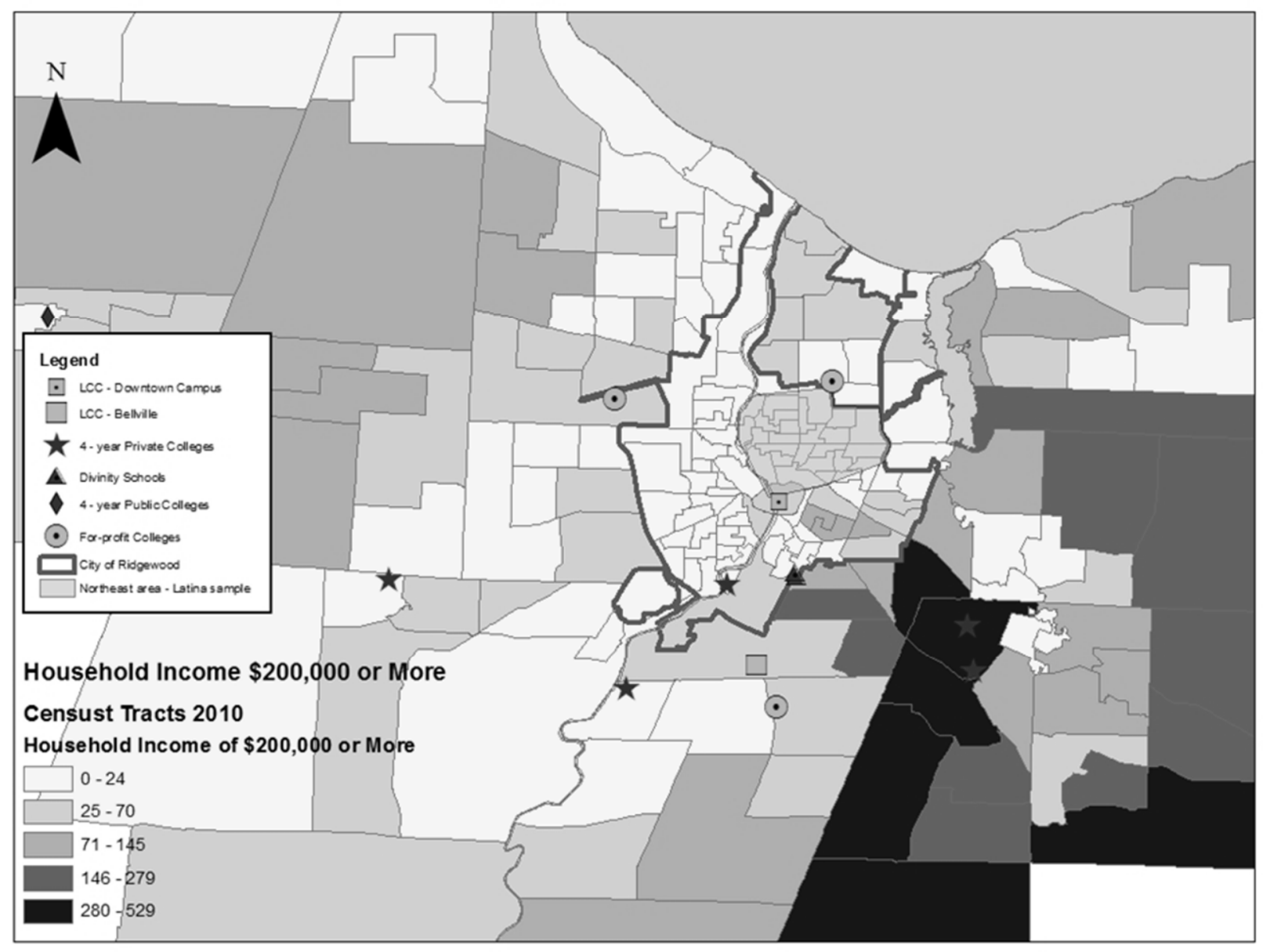

Grade-Level Matters: The relationship to proprietary institutional choice

Finally, we share findings related to Latinas' grade-level in school and their gravitation toward local proprietary institutions. After coding the college choices Latinas were considering, and paying attention to their high school grade-levels, three themes arose. 1) Of the two high school graduates, one was enrolled in the local proprietary institution less than a mile from her home and one intended to apply to a proprietary institution after attending a local community college for half a semester. 2) Most seniors and graduating juniors were seeking to attend 
proprietary institutions, community colleges, or were not applying to college in order to work. The one exception was a student who had not yet learned if her four-year college applications were accepted. 3) Only the traditional juniors and sophomores, who were farthest from graduation, were seeking to attend four-year colleges in the area. When analyzed from a Chicana feminist lens we can better understand the influence that "market segmentation has on future baccalaureate attainment of different ethnic groups as starting at a community college [or proprietary college] substantially reduces a student's chances of getting a bachelor's degree, despite equal academic ability and family background" (Slaughter \& Rhoades, 2004, p. 282). Academic capitalist oriented recruitment intersects with the college choice opportunities lowincome Latina students have in urban areas, which are areas with highest proportions of proprietary institutions. Below are examples of a Latina junior and sophomore's four-year college aspirations:

Well I want, I'm hoping, I want to go to Boston University or Cal U [sic] to be, to go there for pre-med but you know, I want to be a pediatric oncologist.

Angela, high school junior

Pues yo quiero ir para la universidad (Well, I want to go to the university)...[interviewer asked what she wanted to study in college] Eso no sé todavia, [risas] yo quería ser primero maestra, después abogada, pero, ya, no sé. (That I do not know yet, [laughs] I would first like to be a teacher, then a lawyer, but I still do not know).

Sandra, high school sophomore Interestingly, none of the $10^{\text {th }}$ graders indicated a community college or proprietary school as their college aspiration, thus suggesting that the closer to graduation or post-graduation that Latina students in this sample got, the more of a reality proprietary institutions became in their 
college-choice process. Once again, we must examine the structures that limit opportunities for these Latinas. In low-income, urban high schools there is often high counselor turnover, limited time spent with counselors, and an absence of college counselors (McDonough, 1997, 2004), all of which impact the information and preparation students receive about college options and college-going practices. Thus, despite having high college aspirations early in high school, if structures are not in place to make selective college options available, then students will turn to the choices immediately in front of them.

These findings are further understood by examining the trend of Latina students in our sample who enrolled and/or attended local proprietary institutions. Most of the Latina students in this study intended to attend community colleges (40\%). Next, 33\% of Latinas sought to attend four-year colleges in the area. Twenty percent of Latinas were either enrolled or were planning on enrolling at a proprietary institution. If the younger Latinas in this study continue along the same college-choice paths as their graduated or near-graduated Latina peers, it is likely that their four-year aspirations will shift towards community colleges and/or proprietary education by the time they graduate high school. It is also likely that as their four-year aspirations shift, their likelihood of eventually completing a baccalaureate degree will also be reduced. Although the educational aspirations that the Latinas express appear to follow national trends, the socio-spatial data provided in this article paint an important local picture.

\section{Discussion, Implications, \& Conclusion}

The college choice literature has not critically addressed the proprietary paths Latina students are choosing, nor the loan debt that Latina students may accumulate at proprietary institutions from a Chicana feminist lens. Although for-profit institutions increase college access for students of color (Hayes, 2012; United State Senate Committee on Health, Education, Labor 
and Pensions, 2012), there are drawbacks related to decreased social and educational value and high tuition cost of proprietary degrees (United State Senate Committee on Health, Education, Labor and Pensions, 2012). In response to our research questions: (1) What factors influence the college choice decisions of Latina students from low-income urban neighborhoods as they consider proprietary institutions? (2) How does a Chicana feminist analysis further explain the college choice decisions of Latinas from low-income urban areas as they consider proprietary institutions? We find that proprietary institutions target low-income areas and Latina students and communities who suffer the impacts of systems of racial, gender, and capitalist oppression (Bernal, 1998). These forms of oppression are evident in the findings related to geography, distance, financing, marketing, and grade-level in urban Latinas choosing proprietary institutions.

Our findings illustrate that Latinas' college-choice decision-making process was driven by proximity to their home. Some Latina students revealed that they preferred not to travel for college and wished to stay close to home. This decision was related to the expense of traveling to an institution that was further from home and influenced by family obligations and support. It is important to understand these decision processes were rationally and culturally bound (McDonough, 1997). Because the Latinas in our study were less likely to go away for college and were concentrated in areas with more proprietary institutions, they become part of the target market for these institutions.

We also learned how the Latinas in our study made sense of the recruitment strategies proprietary institutions used. Latinas shared that local proprietary institutions frequently recruited at their high schools and led them to believe that certificate and vocational programs had greater value than other degrees. Once the enrollment process began, Latina students 
expressed their concern with the unrealistic viability of being able to financially afford the tuition and fees associated with proprietary institutions. Others were unclear about the types of institutions they were being directed to. Some of the students justified their enrollment decision by expressing their expectation of a concrete employment opportunity upon completion. Ultimately, the students relayed incomplete information about the proprietary institutions, future employment, tuition and fees, and required coursework.

Finally, our findings demonstrate that while all of the Latinas in the study had college aspirations, the closer to graduation or post-graduation that Latina students in this sample got, the more of a reality proprietary institutions became in their college-choice process. Conversely, none of the 10th graders indicated a community college or proprietary school as their college aspiration. Our previous findings help us to understand that students will often turn to the college choices immediately in front of them. In this case, proprietary institutions were closest both in terms of geographic proximity and frequency of recruitment at their local high schools.

Unfortunately, as more prestigious colleges and universities pay more attention to "highquality, high-SES students" and less attention to "historically underserved student populations" (Slaughter \& Rhoades, 2004, pp. 284-285), populations such as the Latinas in our study are left vulnerable to the misinformation and marketing strategies that accompany proprietary recruitment. The disregard at the policy-level of implementing rules that protect students from high debt rather than assist institutions in altering their organizational goals in order to earn profits, ultimately manifests as increasing academic capitalist behavior. "Rather than operating for private gain, higher education institutions were created to serve the public good" (Kinser, 2006, p. 1), a historical point of clarity that reminds us that 'student' did not always equal 'market.' Thus, important implications emerge from our findings. 


\section{Implications}

While federal policies such as the gainful employment rule are a step in assisting students with minimizing debt, we focus our policy implications instead on local school policies that immediately impact the presence and recruitment of proprietary institutions in urban schools. First, we encourage school districts to implement policies regulating the amount of time proprietary institutions spend recruiting students. We believe students should experience the full range of college options, thus, recruiting time should be balanced between for-profit, two-year, and four-year institutions. Likewise, four-year colleges and universities must make it a priority to have a regular presence at local high schools. This is particularly important as students move from their freshmen years of high school into their senior years as our findings demonstrate Latinas' college choices evolved significantly over time.

Although college recruiters in urban high schools provide resources for students on college enrollment and admission, especially in local areas, we find that there also needs to be policies that address college recruitment quality and quantity as it pertains to institutional type. As our study reveals, for-profit institutions and community colleges are in closest proximity to the highest concentrated Latina/o residential area. Our data also indicates that Latina students are less likely to aspire to a 4-year institution as they move closer to graduation, which suggests that there should be a push from 4-year colleges to recruit Latina students as part of their enrollment strategies. This push will challenge the academic capitalist trend that positions students as consumers over learners. We encourage high school and college partnerships across varying institutional types within county and city boundaries. Since there are no policies implemented at the federal and state level that address unethical college recruitment, a consortium of local colleges that evaluates and asses local college recruitment across race and class lines, would 
provide valuable data that assists in developing policies to increase recruitment efforts of Latina students at 4- year colleges. These policy initiatives both extend and compliment previous policy implications on the role that municipalities should play in re-conceptualizing discourses of local college access in low-income communities of color (Dache-Gerbino 2016).

Relatedly, more consistent and present college counseling must be available to students since past research on Latina students reveals that high school personnel also contribute to Latina student channeling into non-academic post high school work (Bernal, 1998). Although underresourced schools struggle with the human and financial opportunities to ensure regular college counseling for all students, we encourage high schools to partner with the breadth of local college, universities, and community organizations so that a visible and consistent college counseling presence is made available for students. Our own studies (see Harris \& Kiyama, 2015) indicate the importance of institutional agents and caring adults when planning for college. These caring adults are essential for helping students to understand the marketing information they are receiving from proprietary and two/four-year institutions.

Finally, we acknowledge that a limitation of this study is that we did not gather institutional data regarding marketing and recruitment practices from proprietary institutions. This is an obvious area for future research and would help to present a more nuanced picture to the arguments we are making in this article, particularly when considering proprietary institutions that claim to focus on access for students of color. And lastly, Nuñez and Crisp's (2012) research is some of the only work that compares the college-choice decisions between Puerto Rican and Mexican American students. We need further research that offers a comparative element among Latina/o subgroups as these students engage in their various college-going paths. 


\section{Conclusion}

Marketing expensive vocational programs to Latina students who cannot afford tuition or the greater likelihood of defaulting on their student loans, contribute to the maintenance of these Latina students' class position as low-socioeconomic and reinforces racial and sexist hierarchies (Bernal, 1998). Cottom (2017) states that women are the gender most represented in for-profit colleges. Being likely primary caregivers to dependent children, working-class women of color (and their families) are susceptible to for-profit marketing (Cottom, 2017). In addition, selling the ideology of workforce training being superior to liberal arts course training is a codified mechanism of post-secondary tracking reinforced by ascribed racializations, stereotypes, and class assumptions (Davila, 2012). It begs the question, are Latina students being herded to attend proprietary institutions due to their symbolic representations? "Market segmentation impacts the baccalaureate attainment of different ethnic groups because starting at a community college substantially reduces a student's chances of getting a bachelor's degree, despite equal academic ability and family background" (Slaughter \& Rhoades, 2004, p. 282). Starting at the proprietary institution would compound these same outcomes as well. These factors account for an environment that implicitly puts Latina students from working-class families at higher risk of believing the dangling carrot as an unbiased college choice.

Notes

${ }^{1}$ Proprietary institutions and for-profit institutions will be used interchangeably throughout this paper

${ }^{2}$ The term Latina/o is used to represent the racial, ethnic, and language diversity representative of Mexican-Americans, Puerto Ricans, Cubans, Dominicans, as well as others from the Caribbean, Central America, and South America. 
${ }^{3}$ All local proprietary institutions and students have been assigned pseudonyms.

${ }^{4}$ This participant quote was used to contextualize agency within Latina students in the publication, Sapp, V. T., Kiyama, J. M., \& Dache-Gerbino, A. (2016). Against all odds: Latinas activate agency to secure access to college. NASPA Journal about Women in Higher Education, 9(1), 39-55.

\section{References}

Alvarez, C. L. (2010). Familial negotiation of the Latina college choice process: An exploration of how parents and their daughters obtain and utilize information to navigate the process. Enrollment Management Journal, 4(4), 57-80.

Astin, A., \& Oseguera, L. (2004). The declining 'equity' of American higher education. The Review of Higher Education , 27(3), 321-341.

Aud, S., Hussar, W., Planty, M., Snyder, T., Bianco, K., Fox, M., Frohlich, L., Kemp, J., Drake, L. (2010). The Condition of Education 2010 (NCES 2010-028). Washington, DC: National Center for Education Statistics, Institute of Education Sciences, U.S. Department of Education.

Bagnato, K. (2004). Republican plan for proprietary colleges draws fire. Black Issues in Higher Education , 21(11), 7.

Bergerson, A. A. (2009). College Choice and Access to College: Moving policy, research, and practice to the 21 st century. San Francisco, CA: Wiley.

Bernal, D. D. (1998). Using a Chicana Feminist Epistemology in Educational Research. Harvard Educational Review, 68(4), 555-582.

Bogdan, R. C. \& Biklen, S. K. (2007). Qualitative research for education. Boston, MA: Pearson Education. 
Cammarota, J. (2004). The gendered and racialized pathways of Latina and Latino youth: Different struggles, different resistances in the urban context. Anthropology and Education Quarterly, 35(1), 53-74.

Campbell, C. \& Deil-Amen, R. (2012). Role reversal in the college admissions process: How forprofits sell themselves. ASHE annual conference, Las Vegas, Nevada.

Chapa, J. \& De La Rosa, B. (2004). Latino population growth, socioeconomic and demographic characteristics, and implications for educational attainment. Education and Urban Society, 36(2), 130-149.

Chung, A. (2008). For-profit student heterogenity. Munich Personal RePEC Archival Paper. Germany: University Library of Munich.

Cottom, T. M. (2017). Lower Ed: The troubling rise of for-profit colleges in the new economy. New York, NY: The New Press.

County Geographic Information Systems. (2011). County GIS General and Parcel Data CD. https://www2.monroecounty.gov/gis-Data.php

Crenshaw, K. (1991). Mapping the margins: Intersectionality, identity politics, and violence against women of color. Stanford Law Review, 1241-1299.

Creswell, J. W., \& Clark, V. L. (2011). Designing and conducting mixed methods research. Thousand Oaks, CA: Sage.

Dache-Gerbino, A. (2017). Mapping the postcolonial across urban and suburban college access geographies. Equity and Excellence in Education, 50(4), 368-386.

Dache-Gerbino, A. (2016). College desert and oasis: A Critical geographic college access analysis of urban decline. Journal of Diversity in Higher Education (JDHE). Advanced online: http://psycnet.apa.org/doi/10.1037/dhe0000050. 
Davila, A. (2012). Culture works: Space, value, and mobility across neoliberal Americas. New York, NY: New York University Press.

Dillard, C. B. (2000). The substance of things hoped for, the evidence of things not seen: Examining an endarkened feminist epistemology in educational research and leadership. International Journal of Qualitative Studies in Education, 13(6), 661-681.

Fisher, C. (2012). The expansion of for-profit colleges for immigrant and minority education: A socio-spatial analysis of for-profit colleges in metropolitan Washington, DC. Dissertation Abstracts 2014 .

Gardner, H. (2006). Five minds for the future. Boston, MA: Harvard Business School Press.

Goble, L. J. (2010). College choice and college success: The role of individuals, institutions and policy. (Unpublished Doctoral Dissertation) North Western University.

Goldrick-Rab, S. (2006). Following their every move: How social class shapes postsecondary pathways. Sociology of Education, 79(1), 61-79.

Harris, D. M., \& Kiyama, J. M. (published online: 2013; 2015). The role of community and school-based programs in aiding Latina/o student high school persistence. Education and Urban Society, 47(2), 182-206. DOI: 10.1177/0013124513495274.

Hayes, D. (2012). The for-profit conundrum: Despite leading the way in minority enrollment, questions surround the value of proprietary institutions' degrees. Diverse Issues in Higher Education , 29(14), 10.

Hossler, D., \& Gallagher, K. S. (1987). Studying student college choice: A three-phase model and the implications for policymakers. College and University, 62(3), 207-222.

Iloh, C., \& Tierney, W. G. (2014). Understanding for-profit and community college choice through rational choice. Teachers College Record, 116, 1-34. 
Kinser, K. (2006). Considering the third sector: The new prominence of for-profit higher education. In From Main Street to Wall Street: For-profit higher education. ASHE Higher Education Report (Volume 31, Number 5; pp. 1-10). San Francisco, CA: Jossey-Bass.

Kiyama, J. M, Harris, D. M., \& Dache-Gerbino, A. (2016). Fighting for respeto: Latinas' stories of violence and resistance shaping educational opportunities. Teachers College Record, $118,1-50$.

Lopez, I. H. (2006). White by law: The legal construction of race. New York, NY: University Press.

McDonough, P. M. (1997). Choosing colleges: How social class and school structure opportunity. Albany, NY: State University of New York Press.

McDonough, P. M. (2004). Counseling Matters: Knowledge, Assistance, and Organizational Commitment in College Preparation. In W. G. Tierney, Z. B. Corwin \& J. E. Colyar (Eds.), Preparing for college: Nine elements of effective outreach (pp. 69-87). Albany, NY: SUNY Press.

Mendoza, M., Hart, J., \& Whitney, S. (2011). Taking the family to college: Understanding the role of family in the resiliency of Hispanic students at a predominantly White Midwest university. Enrollment Management Journal, 5(4), 67-90.

Montoya, M. E. (2006). Forward: LatCrit at ten years. Chicana/o-Latina/o Law Review, 26(1), 114.

National Center for Education Statistics (2014). The condition of education: Public high school graduation rates. Retrieved September 26, 2014 from http://nces.ed.gov/programs/coe/indicator_coi.asp. 
New York State GIS Data Clearinghouse. (2012). New York State street name shapefiles. http://gis.ny.gov/gisdata/

Nieto, S. (1998). Fact and fiction: Stories of Puerto Ricans in U.S. schools. Harvard Educational Review, 62(8), 133-163.

Nieto, S. (2004). A history of the education of Puerto Rican students in U.S. mainland schools:"Losers," "outsiders," or "leaders”? In J. A. Banks \& C. A. Bank (Eds.), Handbook of research on multicultural education (pp. 388-411). San Francisco, CA: Wiley.

Nuñez, A.M. \& Crisp, G. (2012). Ethnic diversity and Latina/o college access: A comparison of Mexican-American and Puerto Rican beginning college students. Journal of Diversity in Higher Education, 5(2), 78-95.

Oseguera, L., \& Malagon, M. (2011). For-profit colleges and universities and the Latina/o students who enroll in them. Journal of Hispanic Higher Education, 10(1), 66-91.

Outcalt, C. L., \& Schirmer, J. H. (2003). ERIC review: understanding the relationships between proprietary schools and community colleges. Community College Reivew, 3(1), 56-73.

Ovink, S. M. (2014). “They always call me an investment.” Gendered familism and Latina/o college pathways. Gender \& Society, 28(2), 265-288.

Perez, P. A., \& McDonough, P. M. (2008). Understanding Latina and Latino college choice: A social capital and chain migration analysis. Journal of Hispanic Higher Education, 7(3), 249-265.

Perna, L. W. (2000). Differences in the decision to attend college among African-Americans, Hispanics, and Whites. The Journal of Higher Education, 71(2), 117-141. 
Pew Research Center. (2013). Hispanic high school graduates pass Whites in rate of college enrollment. Washington, DC: Pew Research Center.

Ridgewood County Geographic Information Systems. (2011). Ridgewood County GIS General and Parcel Data CD.

Rouse, C. E. (1995). Democratization or diversion: The effect of community-colleges on educational-attainment. Journal of Business \& Economic Statistics, 13, 217-224.

Sanchez, T. W., Stolz, R., \& Ma, J. S. (2003). Moving to Equity: Addressing Inequitable Effects of Transportation Policies on Minorities. Cambridge, MA: The Civil Rights Project at Harvard University.

Santiago, D. A. (2007). Choosing Hispanic-serving institutions (HSIs): A closer look at Latino students' college choices. Washington, DC: Excelencia in Education.

Sapp, V. T., Kiyama, J. M., \& Dache-Gerbino, A. (2016). Against all odds: Latinas activate agency to secure access to college. NASPA Journal about Women in Higher Education, $9(1), 39-55$.

Scheurich, J. J., \& Young, M. D. (1997). Coloring Epistemologies: Are our research epistemologies racially biased? Educational Researcher, 26(4), 4-16.

Slaughter, S., \& Rhoades, G. (2004). Academic capitalism and the new economy: Market, state, and higher education . Baltimore, MA: The John Hopkins University Press.

Sy, S. R., \& Brittian, A. (2008). The impact of family obligations on young women's decisions during the transition to college: A comparison of Latina, European American, and Asian American students. Sex Roles, 58(9-10), 729-737. 
Tierney, W. G., \& Hentschke, G. C. (2007). New players, different game: Understanding the rise of for-profit colleges and universities. Baltimore, MD: The Johns Hopkins University Press.

Tierney, W. G., \& Venegas, K. (2009). Finding money on the table: Information, financial aid, and access to college. The Journal of Higher Education, 80(4), 363-387.

Turley, R. N. (2006). When parents want children to stay home for college. Research in Higher Education , 47(7), 823-846.

Turley, R. N. (2009). College proximity: Mapping access to opportunity. Sociology of Education, $82,126-146$.

Turner, C. S. (2008). Toward public education as a public good. In K. P. Gonzalez, \& R. V. Padilla (Eds.), Doing the public good (pp. 97-112). Sterling: Stylus.

United State Senate Committee on Health, Education, Labor and Pensions. (2012). FOR PROFIT HIGHER EDUCATION: The Failure to Safeguard the Federal Investment and Ensure Student Success. Washington, DC: Majority Committee Staff Report And Accompanying Minority Committee Staff Views.

U.S. Census Bureau. (2010). American community survey 5-Year estimates (2005- 2010). https://factfinder.census.gov/faces/nav/jsf/pages/index.xhtml

U.S. Department of Education. (2011). Obama Administration announces new steps to protect students from ineffective career college programs. Retrieved June 2, 2011 from http://www.ed.gov/news/press-releases/gainful-employment-regulations.

Weisbrod, B. A., Ballou, J. P., \& Asch, E. (2008). Mission and money: Understanding the university. New York, NY: Cambridge University Press. 